\title{
Maya America: Journal of Essays, Commentary, and Analysis
}

$4-29-2020$

\section{Challenges for Maya Family Continuity in a Transbordered World}

\author{
James Loucky \\ Western Washington University \\ Katie Goger \\ Lummi Nation Parental Health Program
}

Follow this and additional works at: https://digitalcommons.kennesaw.edu/mayaamerica

Part of the Ethnic Studies Commons, Indigenous Studies Commons, and the Latina/o Studies Commons

\section{Recommended Citation}

Loucky, James and Goger, Katie (2020) "Challenges for Maya Family Continuity in a Transbordered World," Maya America: Journal of Essays, Commentary, and Analysis: Vol. 2 : Iss. 1 , Article 17.

DOI: $10.32727 / 26.2021 .21$

Available at: https://digitalcommons.kennesaw.edu/mayaamerica/vol2/iss1/17

This Article is brought to you for free and open access by DigitalCommons@Kennesaw State University. It has been accepted for inclusion in Maya America: Journal of Essays, Commentary, and Analysis by an authorized editor of DigitalCommons@Kennesaw State University. For more information, please contact digitalcommons@kennesaw.edu. 


\title{
Challenges for Maya Family Continuity in a Transbordered World
}

\author{
James Loucky \\ Western Washington University \\ Katie Goger \\ Lummi Nation Parental Heath Program
}

\begin{abstract}
Migration between Central America and countries to the north has increased in scale as well as in contentiousness as a political challenge. Too often, those most involved are peripheral to public discourse and policies. Today sizeable numbers of families, including indigenous Maya families, are participants not only in movement but as through separations across national borders and time. Evolving strategies for maintaining or recreating social cohesion amid disruptions of migration and resettlement involve parents as well as children. Drawing on experiences of families from one highland Guatemalan community, and comparative research into adaptive strategies of immigrant families in the United States, we argue for the necessity of acknowledging current realities and shifting familial challenges that characterize millions of people in North America today.
\end{abstract}

Keywords: Maya, migration, transnationalism, displacement, family separation

\section{Introduction}

Contemporary realities for much of humanity include movement and social reconfigurations that this generates. Challenges are exacerbated further by harmful politics of exclusion and looming planetary disruptions. The Americas, whose name connotes a time of mass migration, is setting for north-south geographic and historical contours that are now reflected in narratives of tens of millions of people. As destinations become destinies, families are where transborder migration dynamics play out. While geopolitics command attention, families are where we come to understand intergenerational commitments and whether future scenarios may align with ideals like e pluribus unum, in counterbalance to contentiousness and misperceptions that prevail today.

Representative of cultures that acknowledge kinship as fundamental to existence are the Maya. Well known through archaeology and cultural anthropology, indigenous Maya are now also prominent in large-scale emigration from Mesoamerica (Loucky \& Moors 2000). Their displacement is rooted in long colonial inequities and subsequent domination of the United States over Mesoamerica and much of the hemisphere. As violence 
and environmental degradation provoke epic levels of migration from the mid-section of the Americas, comprised of Guatemala, El Salvador and Honduras and referred to as the "northern triangle," it occurs in corridors that are increasingly criminalized and militarily curtailed (Miller 2019). Comprising roughly half of the population of Guatemala, Maya now face contracting possibilities, such that "survival migration" has become continental in scope (Jonas \& Rodriguez 2015; Suro 2019). Today, however, policies of prevention through deterrence creates ever more insecurity, as faces of fear of Maya children and families on the U.S.-Mexico border attest.

Evidence from a Maya community in highland Guatemala, and related research in the United States, reveals how families are vital for social cohesion and transformation amid the disruptions of migration and resettlement. They are central to understanding adaptive strategies and future social configurations, particularly because of roles of mothers and children (Abrego 2014; Hondagneu-Sotelo \& Avila 1997; Menjívar 2006). Our focus here is on how absence of a parent reveals potentials for enduring challenges of separation, through flexible supportive arrangements that transcend boundaries of place and passage of time.

\section{Transborder Family Separations}

The paradox of separating in order to stay together is recurrent experience of families throughout history and remains so today throughout the world. Families are primary settings for care and continuity, especially prior to, during, and following movement, whether it occurs as flight from endangerment or as means for procuring necessities of life. Research has tended to be directed toward those on the move, even though far more people do not move. Single men have also predominated in past accounts of migration (Mahler \& Pessar 2006), with women and children assumed either to be "left behind" or to follow male family members, following resettlement or payment of debts incurred in migrating (Dreby 2010; Hondagneu-Sotelo \& Avila 1997; Parreñas 2005; Schmalzbauer 2005). In actuality, women and children are woven into the intricacies and reorganizations of movement, making their experiences essential for accurately delineating the nature and implications of phenomena which commonly involves families.

Our attention centers on how families negotiate and adjust to movement of their members. Women, through their roles as mothers as well as partners, contend with emotional intrusions and turbulence of family life, including those associated with needs and livelihoods of children. In responding to conditions that impel or follow migration, they are continuously involved and invested in decisions. Parental investment is particularly 
essential during times of precarity. Sustaining families through providing safety, mutuality, and childcare may entail shifting care-giving responsibilities, composition, and even residence, frequently with intentions that these are temporary, in order to maintain long-term familial connectedness.

Both parenting from afar and being separated from parents complicate family wellbeing (Abrego 2014, 2016; Boehm 2018; Casteñeda 2019; Dreby 2010; Hersberg \& Lykes 2012, 2015; Zentgraf \& Chinchilla 2012). Migration, particularly when distant or across national borders, entails adjustments that may be stressful for those who move, as well as those who do not (Lykes \& Sibley 2013; Suárez-Orozco, Todorova, \& Louie 2002). Research on separated families highlights varied outcomes, many of them dismal; marriages often disintegrate, women suffer anxiety and depression, and remittances may diminish, while children face tough adjustment challenges, in the face of fragmentation, disorientation and alienation that can threaten family relations (Getrich 2019; Castañeda \& Buck 2011; Menjívar 2006; Menjívar \& Abrego 2009; Moran-Taylor 2008).

Absent bonds of attachment in secure parent-child relationships, children may experience diminished psychological wellbeing (Ainsworth 1989; Bowlby 1988; Brabeck, Lykes, \& Hunter 2014; Castañeda \& Buck 2011). Children in the United States, many of whom are U.S. citizens, are also at risk for lower educational and social outcomes when experiencing separation from a deported or detained parent (Capps, et al. 2007; Cardoso, et al. 2018). With an estimated 5.5 million children in the United States having undocumented parents, prospects are especially sobering in cases of lengthening parental separation (Chaudry, et al. 2010), similar to emotional and behavioral outcomes that occur when a parent is incarcerated or deployed in the military (Allen, et al. 2013). Navigating the detrimental separation effects of draconian incarceration or deportation policies is particularly challenging.

Amid such circumstances, it is notable that many families demonstrate resiliency in overcoming the disruptive impacts of migration-related separation (Abrego 2016; Hershberg \& Lykes 2015, 2019; Walsh 2006). In both the United States and Guatemala, women in separated families are central to income generation and caregiving, as well as prioritization of schooling so children become bien educado (well educated). Together these represent strategies that are nowhere more positive and essential than in situations of parenting from afar.

Migration Viewed From The South: The Case Of Aguacatán

Aguacatán, a community in the north-central highlands of Guatemala, exemplifies 
how landlessness, poverty, and rural isolation combine to lead to high emigration (Camus 2008). As long as fifteen years ago, a quarter of the population was estimated to have left for the United States, and that figure is undoubtedly higher today. Women and children now comprise increasing proportions of Aguacatecos in the United States, in concentrations across the "sun belt" but also beyond, from the Pacific Northwest (such as Whatcom County, in Washington state) to the Midwest and along the eastern seaboard. Interviews with twenty-five women, each having a spouse in the United States, were conducted in Aguacatán in November 2011. Complemented by reviewing research with mixed-status and immigrant families in the United States, these reveal considerable challenges but also coping strategies that involve different forms of caregiving, managing household finances, and becoming adept at novel forms of communicating with family members, whose lives span Guatemala and el norte (the north), as the United States is known.

\section{Parenting}

Parenting, a rewarding but emotionally and physically demanding role, is intensified for single parents. Of the interviewees, over half said their male partners had ambiguous plans to return to Guatemala. The Director of the Municipal Woman's Office in Aguacatán described the family disintegration as a result of male emigration as one in which a man may form a new relationship, such that women may need to "start looking for a new marriage to survive." Most women spoke of the possibilities that financial support from a spouse in the United States may be cut unexpectedly. Consequently, mothers in Aguacatán initiate economic activities out of necessity. In response, extended family members employ different forms of organizational support as they take on additional roles to accommodate for a fathers' absence. Women provide intensive parenting to ameliorate the effects of family separation, and in so doing, restructure traditional male authority within the household.

Children and adolescents must also adjust. Asked if she had a boyfriend, an 18-yearold said, "No, my dad [in the U.S.] says I'm too young." Distant fathers attempt to maintain familial duties, primarily through using telephone and computer connections to show authority and impose discipline (Parreñas 2005). Effectiveness varies, however. As

another adolescent reported: "My dad came home after being gone for eight years. I didn't want anything to do with him. He gave money and bought food, but he's not my dad." A school counselor explained: "Younger children only care if they have good shoes, money and nice clothes. But it changes with the older kids. They start saying they'd rather have him here, than all the stuff." An unmarried older adolescent was circumspect: "I'd like to have [my father] around but honestly, living apart allows me to attend private school, and 
receive an education for a job someday."

Left with pressure to reciprocate for families, some youth take advantage of opportunities, while others engage in risky behaviors, as a school director reports:

A lot of women say it is good for their spouse to go to the United States, but it's not. They give money but there is no love. No father, no relationship. These children have a lot of problems. There is no dad to enforce rules and kids 11 to 16 years old start drinking, smoking marijuana or become pregnant.

Attempting to impose influence from afar often backfires for fathers because children feel disconnected and may rebel. And yet, while her mother nodded in agreement, another young woman saids of her U.S.-based father, "He gives us advice. Like he tells us what he thinks. Says not to drink, gives us rules." As with many two-parent households, parenting is easier when both parents are working together for similar outcomes for their children.

\section{Remittances}

Remittances are central to meeting migratory goals so that toils of work and parenting across borders have positive result (Castañeda \& Buck 2011; Dreby 2010). Often, however, remittances are insufficient to meet needs. Nearly half of sampled families reported using remittances solely on food (corn, crops and market items), yet the next largest single expense was split evenly between school, medicine, and housing, and less frequently to make loan repayments. Various benefits of money coming from abroad were elaborated by one woman:

Thirteen years ago, the remittances were very good. We were able to buy a house and get a computer with internet for my son studying technology. But remittances have been less in the last few years. By the time my husband pays for lights, telephone, water, and rent in the United States, there is little money left for us.

A majority of Aguacateco families rely on cash flows from the United States. Families who receive consistent remittances have access to more resources than those receiving fewer, or no, remittances. Their experience is consistent with research showing children in origin countries to have more confident relationships with fathers when remittances from them are consistent (Castañeda \& Buck 2011; Hershberg \& Lykes 2012, 
2019; Zentgraf \& Chinchilla 2012).

\section{Exchange of Knowledge}

Non-monetary remittances are ways cultural transmission is realized across borders. The bi-directional flow of cultural products offers both resiliency and emotional connection to family members. In the midst of hardships, the exchange of products advertises and legitimizes the migration experience, both to themselves and to their community. As one mother put it:

[See] all the stuff that people have to show that they've made the "American dream." Like those big houses around town. The kids at Juan's school with fathers in the States send them money for nice cell phones just to show that they're making money up there. It's like when you see someone with nice things and think, wow what do they do to be able to buy that? But it works. People see nice things and it makes us want to go.

In other words, women in Guatemala are as much a part of the migration experience as male counterparts. Migrants maintain strong transnational connections to their sending regions by exchanging products, an example of how culture is tangibly sent and received. A mother described, "We mail him pepita, (squash seeds), chile, medicine - things he likes from here. He mails us shoes and clothes for the children." Such transnational interactions are essential as migration has become a way of life, that many families can no longer live without.

\section{Communicating from Afar}

Among ways for creatively maintaining spousal attachments, and in turn providing secure bonds for children, most parents now utilize modern benefits of technology (cell phones, internet, and money transfers). Use of electronic communications is ubiquitous, although this reality emerged largely in just the past decade. In the 1980s and 1990s, communications with people who left for el norte relied largely on occasional and expensive phone calls, or else cassette tapes carried by people moving between the two countries (facilitating communication with family members who were not literate). By 2011, interviews reveal emerging use of social media and cell phones. Today WhatsApp and Facebook are ubiquitous, and even young children are often seen on cell phones. It remains to be seen whether increasing access to such technologies translates into greater family resilience along with more frequent communicating. Length and frequency of 
phone calls were largely dependent on remittances a decade ago, but cost of phone calls is far less of a barrier today; an average conversation used to be 15-30 minutes weekly, while today many women talk daily for at least that long.

Video chatting and recording also serve as important tools for recording critical life events, though they entail psychological risks and induce economic barriers (Cuban 2017). Visual images of parents and loved ones can stir emotions, said one adolescent:

We usually talk every week or every two weeks. Unless he is back together with his girlfriend, then we don't hear from him or get as much money. I've seen my dad's new girlfriend and met my half-brother through Skype, but I didn't like it at all. I got a bad feeling because they had all these nice things in the house and we don't even have a floor, food, shoes, money for school.

This father did not send consistent remittances to the family because he was supporting his new relationships in the United States. It was evident that this family lived in greater poverty in comparison to women who maintained communication with a spouse and received funds.

\section{The View from the North}

Seeing migration through lived experiences not only involves families in towns like those across the Guatemalan highlands, but also families who may no longer be physically in such places yet remain connected to them. The significance of immigrant families lies in intergenerational and cultural continuities, along with civic commitments and unrivaled hard work. Their lives are also heavily impacted by the increasingly draconian nature of immigration policies, like those of deportation or discrimination, whose social costs are borne by those not directly targeted as much as by those that are. Being suspect of, or criminalized for, "being immigrant" serve as ongoing threat, even for families that include members with legal status.

With family stability so crucial to child development, long-term implications for children are of particular concern for those in undocumented or mixed status families. Persistent disconnect between protocols regarding child and family protections and the inhumanities of current U.S. immigration policies strongly affects the futures of young people, even those having long residence in the United States. Uncertainties and limited resources characterize family contexts for many of the estimated $5+$ million children in the United States who have a parent who is undocumented (Castañeda, 2019; Phinney 
\& Vedder, 2006). With large numbers living below the federal poverty line, poverty compounds lack of legal status to create cumulative barriers that carry over from parents to children (Gonzales, 2009).

Parents in families that are mixed-status or comprised of undocumented members report children to be less healthy overall, something that in turn can result in developmental delay. Trauma associated with separation and fear of raids has been found to lower overall child wellbeing, creating adverse mental health and cognitive outcomes that can extend across a lifespan (Arbona, et al. 2010; Dreby 2012; Giano, et al. 2019; The Urban Institute 2010). Ineligibility for housing assistance is linked to crowded living space, in turn contributing to lower academic achievement, high blood pressure, and behavioral problems at school (Yoshikawa \& Kalil 2011). Unavailability or unawareness about resources and presumed or actual ineligibility (such as for preschool education) impact achievements, even as limited schooling of parents may lessen their ability to provide guidance about negotiating the school system (Yoshikawa 2011). Social, financial, and psychological distress in parents who lack legal status may incline them towards being less warm towards children, as revealed in research into strains on familial relationships in mixed-status families (Brabeck, Lykes, \& Hunter 2014). Not surprisingly, open parentchild communication may be compromised when threats to family cohesion and financial wellbeing emerge as fears, sadness, or precautionary behaviors (Hershberg \& Lykes 2012; Lykes, Brabeck, \& Hunter 2013).

Risk to families and children are especially high when parents are ensnared by the criminal justice system. The cases of Postville, Iowa, and New Bedford, Massachusetts, in which hundreds of Maya (many of them parents of U.S.-born children) were deported after workplace arrests in what a decade ago were the largest immigration raids the U.S. had yet seen, resulted in family disintegration, loss of income and childcare, and subsequent difficulties in obtaining basic needs for children. The harms of an enforcement regime that has separated families, caged children and tolerated unwanted diversion into foster care continue to haunt and harm thousands of children and families, many from Mesoamerican communities where family integrity has been central to life itself.

\section{Continuing Challenges Of Intergenerational And Transnational Realities}

Transnational migration requires re-creating social arrangements for family functioning, not only in response to changes in locations but also, as in the case of Guatemala and the United States, within a thorny political context. Determination to provide family connectedness is seen in various cross-border communication and caring 
practices. But experiences of separated Maya families also reveal considerable obstacles facing families south and north in their struggle to improve lives of their children.

Poor employment prospects, insufficiency of arable land, and systemic racism continue to be problematic in highland communities. As an Aguacatec woman reported in 2019, families still make the arduous trip north, as they did a decade ago: "If we stay, we will starve to death. In both rural and urban areas, there is malnutrition and no jobs. It hasn't rained, many homes haven't had a corn harvest, and there's no work." Separations can be occasions for women to realize agency within changing family structures, yet this woman's perspective also reveals the uncertainty of depending on transnational arrangements. With remittances halved, and her father and brother spending much of their time locked in their apartment, fearful of deportation, she laments lost dreams of building a house and creating a new business, and predicts even more women will accompany or join husbands in the United States: "Parents may only take one or two of the youngest children, until they make some money, and leave the older ones since they don't need as much care." Concerns also revolve around rebellion and eroded ability of grandmothers and aunts to control teens. For their part, youth are increasingly included in immigrant narratives, as decreasing school enrollment (dropping 20\% in just the last year) suggest. Fighting for better living conditions, along with possibilities for migrating, appear to be increasingly and yet also disheartening sentiments.

As in Guatemala, children in the United States are also impacted by kin-making practices and psychological wellbeing, even as parents and communities are impacted in turn by what their children experience. Access to social measures is beneficial, but children are rarely autonomous or able to access services on their own. Policies and programs call for prioritizing the formative and nurturing roles of families, including parent-child, sibling, and extended kinship relations. This is even more critical when unauthorized people are identified by immigration agencies or subject to detention or removal proceedings. Preventing separations that place parents in remote locations that curtail contact, and children in places or with people who may be new as well, is imperative. Evidence-based treatment services and educational strategies that involve both parents and children are essential. Trusted mentors and community-based approaches that attend to daily and emotional needs of both children and parents are paramount. These will be most effective when they involve social resources and services that span transnationalized societies and governance arrangements.

Despite U.S. immigration policies that marginalize children and families, families also show remarkable resiliency in sustaining individuality and agency. When combined with societal support, their strategies and values have great potential for inclusion and 
overall community wellbeing. Never has this been more needed than during migratory and multicultural realities that will continue to define the United States and the world of tomorrow. The Maya are exemplary of transnational and intercultural dimensions that demand acknowledgment, insofar as movement is not only spatial and temporal, but lived through family relations which remain the foundation of communities everywhere.

Author Bios: James Loucky has worked with Maya families in highland Guatemala since the 1970s, and thereafter with Central American and Mexican-descent communities in the United States, as well as on U.S.-Mexico border issues. Following graduate and post-graduate work at UCLA, he began work as anthropologist at Western Washington University, in 1990. His humanitarian and applied commitments are evident in child and family advocacy, as well as collaborative involvement around protections and rights to move in a world of mounting political and planetary challenges. In addition to co-developing the online journal "Maya America," he speaks and writes about the Maya diaspora, provides expertise in political asylum cases, and works to support indigenous cultural determination and environmental restoration efforts. Katie Goger received her bachelor's degree in social sciences from California Polytechnic State University and her master's degree in anthropology from Western Washington University in 2012. She currently is completing her Master of Social Work at Boise State University with anticipated completion in fall 2020. She has over ten years of experience providing evidence-informed parenting prevention and intervention programs, specifically to tribal communities. She continues her work in supporting Indigenous families in her position as a parenting specialist at Lummi Nation Behavioral Health in Bellingham, Washington. Specific interests include participatory action research, separated parenting, intergenerational trauma, parentchild attachment, and mindfulness approaches for children and families. 


\section{References}

Abrego, Leisy. 2014. Sacrificing Families: Navigating Laws, Labor, and Love Across Borders. Stanford University Press.

-. 2016. "Illegality as a Source of Solidarity and Tension in Latino Families." Journal of Latino/Latin American Studies 8, 5-21. https://doi.org/10.18085/1549-9502-8.1.5.

Ainsworth, Mary S. 1989. "Attachments Beyond Infancy." American Psychologist, 44(4), 709-716. DOI: 10.1037/0003-066X.44.4.709.

Allen, Brian, Erica Cisnerso, and Alexandra Tellez. 2015. "The Children Left Behind: The Impact of Parental Deportation on Mental Health.” Journal of Child and Family Studies 24, 386-392. https://doi.org/10.1007/s10826-013-9848-5.

Arbona, Consuelo, Norma Olvera, Nestor Rodriguez, Jacqueline Hagan, Adriana Linares, and Margit Wiesner. 2010. "Acculturative Stress among Documented and Undocumented Latino Immigrants in the United States." Hispanic Journal of Behavioral Sciences 32(3), 362-384. https://doi.org/10.1177/0739986310373210.

Boehm, Deborah A. 2018. Returned: Going and Coming in an Age of Deportation. University of California. https://doi.org/10.1525/9780520962217.

Bowlby, John. 1988. A Secure Base: Parent-Child Attachment and Healtby Human Development. Basic Books.

Brabeck, Kalina M., Brinton M. Lykes, and Cristina Hunter. 2014. "The Psychosocial Impact of Detention and Deportation on US Migrant Children and Families." American Journal of Orthopsychiatry 84(5), 496-505. https://doi.org/10.1037/ort0000011.

Camus, Manuela. 2008. La Sorpresita del Norte: Migración Internacional y Comunidad en Huebuetenango. Guatemala: Instituto Centroamericano de Desarrollo y Estudios Sociales.

Capps, Randolph, Rosa Maria Castañeda, Ajay Chaudry, and Robert Santos. 2007. Paying the Price: The Impact of Immigration Raids on America's Children. The Urban Institute.

Cardoso, Jodi Berger, Jennifer L. Scott, Monica Faulkner, and Liza Barros Lane. 2018.

"Parenting in the Context of Deportation Risk." Journal of Marriage and Family 80(2), 301-316. https://doi.org/10.1111/jomf.12463.

Castañeda, Heide. 2019. Borders of Belonging: Struggle and Solidarity in Mixed-Status Immigrant Families. Stanford University Press. https://doi.org/10.1111/j.1557-203X.2011.01136.x.

Castañeda, Ernesto, and Lesley Buck. 2011. "Remittances, Transnational Parenting, and the Children Left Behind: Economic and Psychological Implications." The Latin Americanist 55(4), 85-110.

Chaudry, Ajay, Randy Capps, Juan Manuel Pedroza, Rosa Maria Castañeda, Robert 
Santos, and Molly M. Scott. 2010. Facing our Future: Children in the Aftermath of Immigration Enforcement. The Urban Institute. https://doi.org/10.1037/e726272011001.

Cuban, Sondra. 2017. Transnational Family Communication. Palgrave Macmillan. https:// doi.org/10.1057/978-1-137-58644-5.

Dreby, Joanna. 2010. Divided by Borders: Mexican Migrants and their Children. University of California.

-. 2012. "The Burden of Deportation on Children in Mexican Immigrant Families." Journal of Marriage and Family 74, 828-845.

-. 2015. Everyday Illegal: When Policies Undermine Immigrant Families. University of California.

Getrich, Christina. 2019. Border Brokers: Children of Mexican Immigrants Navigating U.S. Society, Laws, and Policies. University of Arizona. https://doi.org/10.2307/j.ctvcj2qm1.

Giano, Zachary, Machele Anderson, Karina M. Shreffler, Ronald B. Cox, Jr., Michael J. Merten, and Kami L. Gallus. 2019. "Immigration-Related Arrest, Parental Documentation Status, and Depressive Symptoms among Early Adolescent Latinos." Cultural Diversity and Ethnic Minority Psychology. https://doi.org/10.1037/cdp0000299.

Gonzales, Roberto G. 2009. "On the Rights of Undocumented Children." Society 46(5), 419-422. https://doi.org/10.1007/s12115-009-9240-7.

Hershberg, Rachel, and M. Brinton Lykes. 2012. "Redefining Family: Transnational Girls Narrate Experiences of Parental Migration, Detention, and Deportation." Qualitative Social Research, 14(1), Art. 5.

-. 2015. "Transnational Mixed-Status Families: Critical Challenges in Cross-Border Relationships over Time.” In A. Schueths \& J. Lawston, Eds. Living Together, Living Apart: Mixed Status Families and US Immigration Policy, 37-53. University of Washington.

-. 2019. "Fathering within Transnational and Mixed-Status Mayan Families: An Exploratory Study." International Perspectives in Psychology: Research, Practice, Consultation 8(2), 59-77. https://doi.org/10.1037/ipp0000104.

Hondagneu-Sotelo, Pierrette, and Ernestine Avila. 1997. 'I'm here, but I'm there': The Meanings of Latina Transnational Motherhood." Gender é Society 11(5), 548-570. https://doi.org/10.1177/089124397011005003.

Jonas, Susanne, and Néstor Rodriguez. 2015. Guatemala-U.S. Migration: Transforming Regions. University of Texas.

Loucky, James, and Marilyn Moors. 2000. The Maya Diaspora: Guatemala Roots, New American Lives. Temple University. 
Lykes, M. Brinton, and Erin Sibley. 2013. "Exploring Meaning-Making with Adolescents 'Left Behind' by Migration.” Educational Action Research 21(4), 565-581. https://doi.or g/10.1080/09650792.2013.832346.

Lykes, M. Brinton, Kalina M. Brabeck, and Cristina J. Hunter. 2013. "Exploring Parent-Child Communication in the Context of Threat: Immigrant Families Facing Detention and Deportation in Post-9/11 USA." Community, Work and Family 16(2), 123-146. https://doi.org/10.1080/13668803.2012.752997.

Mahler, Sarah J., and Patricia R. Pessar. 2006. "Gender Matters: Ethnographers Bring Gender from the Periphery toward the Core of Migration Studies." International Migration Review 40(1), 27-63. https://doi.org/10.1111/j.1747-7379.2006.00002.x.

Menjívar, Cecilia. 2006. "Family Reorganization in a Context of Legal Uncertainty: Guatemalan and Salvadoran Immigrants in the United States." International Journal of Sociology of the Family 32(2), 223-245.

Menjívar, Cecilia, and Leisy Abrego. 2009. "Parents and Children Across Borders: Legal Instability and Intergenerational Relations in Guatemalan and Salvadoran Families.” In N. Foner (Ed.), Across Generations: Immigrant Families in America, 160-189. New York University.

Miller, Todd. 2019. Empire of Borders: The Expansion of the US Border Around the World. Penguin.

Moran-Taylor, Michelle J. 2008. “When Mothers and Fathers Migrate North: Caretakers, Children, and Child Rearing in Guatemala." Latin American Perspectives 35(4), 79-95. https://doi.org/10.1177/0094582X08318980.

Parreñas, Rahcel Salazar. 2005. Children of Global Migration: Transnational Families and Gendered Woed. Stanford University Press.

Phinney, Jean S., and Paul Vedder. 2006. "Family Relationship Values of Adolescents and Parents: Intergenerational Discrepancies and Adaptation.” In Berry, Phinney, Sam, and Vedder (Eds.) Immigrant Youth in Cultural Transition: Acculturation, Identity, and Adaptation Across National Contexts, 167-184. https://doi.org/10.4324/9780415963619-7.

Schmalzbauer, Leah. 2005. Striving and Surviving: A Daily Life Analysio of Honduran Transnational Families. Routledge.

Suárez-Orozco, Carola, Irina L.G. Todorova, and Josephine Louie. 2002. "Making Up for Lost Time: The Experience of Separation and Reunification among Immigrant Families." Family Processes 41(4), 625-643. https://doi.org/10.1111/j.15455300.2002.00625.x.

Suro, Roberto. 2019. "A Migration Becomes an Emergency: The Flight of Women and Children from the Northern Triangle and its Antecedents." In Suárez-Orozco, 
Marcelo M., (ed.) Humanitarianism and Mass Migration: Confronting the World Crisis. University of California. https://doi.org/10.2307/j.ctv9zchv9.7.

The Urban Institute. 2010. "Facing our Future: Children in the Aftermath of Immigration Enforcement." Foundation for Child Development.

Walsh, Froma. 2006. Strengthening Family Resilience, 2nd ed. Guilford Press.

Yoshikawa, Hirokazu. 2011. Immigrants Raising Citizens: Undocumented Parents and their Young Children. Russell Sage.

Yoshikawa, Hirokazu, and Ariel Kalil. 2011. "The Effects of Parental Undocumented Status on the Developmental Contexts of Young Children in Immigrant Families.” Child Development Perspectives 5(4), 291-297. https://doi.org/10.1111/j.17508606.2011.00204.x.

Zentgraf, Kristine, and Norma Stoltz Chinchilla. 2012. “Transnational Family Separation: A Framework for Analysis.” Journal of Ethnic and Migration Studies 38(2), 345-366. https://doi.org/10.1080/1369183X.2011.646431. 